\title{
EDITORIAL
}

\section{Environmental Education and the Biosphere}

$\mathrm{W}$ riting from as many different continents, three of us recently proposed an 'International Year of The Biosphere' (Vallentyne et al., 1980) for which it was hoped the United Nations and other International Organizations would designate 1982. This would be just a decade after the UN Conference on the Human Environment, held in Stockholm in 1972, had first brought home very widely to politicians and governments the vital need to care for the world's environment, and would seem to constitute a suitable time-lapse to assess subsequent progress or lack of it. But now, having divined that the UN are at best lukewarm to this proposal, we believe we have a better idea as indicated in the note immediately following this Editorial.

\section{The Biosphere and Its Need of Protection}

Our main objective in proposing such a 'Year' was, however, to call attention to, and advocate some possible means of remedying, the widely-prevailing public ignorance concerning the Biosphere, which is such that the vast majority of people living in it_-as of course all people normally do-simply do not understand what it is, much less 'realize how utterly dependent they are on it for their life-support and very existence' (Ibid.). Indeed, it seems probable that most of the $c a 4.5$ thousand million people now living on Earth are totally unfamiliar with this very concept of Biosphere, even though many will have heard the term in some language. As a piece of self-discipline and a tiny start in the wider world, we propose henceforth in our own writings to dignify the term by capitalizing its initial letter and, starting with this Editorial, writing Biosphere (sic) after the manner of 'Earth', 'Man', 'Sun', and a few other leading concepts in this our Journal.

The Biosphere has been variously defined and considered (e.g. Polunin, 1972; Ehrlich et al., 1977), but seems best described as 'the peripheral envelope of the Earth together with its surrounding atmosphere in which living things exist, ranging from the deepest layers of soils and [bottoms of 'trenches' in] oceans, upwards to the highest levels of the atmosphere in which any form of life - including dormant spores or bacterial or other cells - is present at all naturally. (By use of the last phrase, we exclude artificial projections into space and descents into deep mines, etc.)' (Polunin, 1980). The rather novel theme of the 'Ethics of Biospheral Survival' was dealt with in the 5 parts (emanating from 4 different continents) of the keynote paper and its discussion (involving the Chairman of the Session, 2 of the Authors, 3 special Panellists, and at least 11 other discussants introducing yet another continent), in our Second International Conference on Environmental Future (Willard et al., 1980).

The International Year of The Biosphere was proposed 'As a practical step towards creating the necessary public understanding, [engendering a feeling of 'togetherness' among inhabitants of our 'only one Earth',] strengthening measures for the welfare of mankind, and developing initiatives for safeguarding' this 'total ecological system of our planet Earth' (Vallentyne et al., 1980). It is also felt that the Biosphere should be a central theme of environmental education, which itself could benefit substantially from recognizing and acting on this virtual imperative.

Acquiring all the knowledge possible about the Biosphere, and disseminating this knowledge to all the quarters and peoples of the globe, are such paramount needs - as population-pressures increase and the world's resources tend to be reduced concomitantly - that we feel strongly that far more than hitherto should be done to further these objectives. Consequently we urge that, if the 'Year' does not come off as proposed, or even if it does, some alternative means of attaining the same objectives of information, concern, and much-needed action, should surely be worked out and pursued with the utmost vigour and protracted dedication-hence our further proposal published in the note following this Editorial. For the Biosphere is not so robust that we do not need to know all we can gather about it - throughout the world, with the oceans and atmosphere which complete its extent-in order to cherish and protect it.

\section{Importance of Environmental Education}

The necessary knowledge is mainly acquired by direct observation or research-whether this be 'basic' or 'applied' - and the dissemination of this knowledge is accomplished through learned or other journals and books, conferences and other meetings, and the information 'media' of popular press, radio, television, cinema, etc. These are leading tools of environmental education, which needs to be furthered in every way possible towards due environmental awareness and cognate safeguarding of the Biosphere.

Consequently we were very pleased recently to address an impressive and widely international conference on environmental education-held in Berne, Switzerland, during 29 March-2 April 1980-concerning this urgent need for the dissemination of far more knowledge, both academic and public, about the Biosphere, and doubly delighted when they passed unanimously a resolution (of which we had no previous inkling) to support our initiative in this matter (Hughes-Evans, in press). There had been a First European Conference on Environmental Education held under similar auspices two years earlier in London, England-some months before the first Intergovernmental Conference on Environmental Education took place in Tbilisi, USSR.

In addition to this special resolution supporting our proposal 'that 1982 should be the International Year of the Biosphere' (D. Hughes-Evans in litt. 12 April 1980), and as a special example, the Berne conference supported our plea for special attention to be given to the urgent need to prepare agricultural directors and individual farmers to be less conservative than hitherto in the matter of desirable change - so that the innovations which we are told could save the world from starvation in future will have a reasonable chance of widespread adoption. For the agricultural sector tends all-too-widely to constitute about the most conservative community on Earth, resisting any change that is not clearly to their own immediate advantage - even sometimes when it is demonstrably so - and often, in the 
case of down-to-earth farmers, being sadly suspicious of any major innovation. Yet such will be needed--including new and better crops and practices - if the ever-increasing human population of the world is to be fed and accommodated at all adequately as a whole and equably in different regions. Consequently, control of this population should be our basic and long-term imperative, even as it lay behind our 'Reykjavik Imperative on the Environment and Future of Mankind' (Foundation for Environmental Conservation, 1977).

It is for such reasons and urgent purposes that education in general and environmental education in particular is so vastly important. Consequently, we were much interested to participate in the planning, with participants and sponsors of the Berne conference, of an 'International journal of environmental education' (whatever it may come to be called), ${ }^{*}$ which should fulfil a vital need and be most warmly welcome. At present there is no international journal in this field, and so it is very much to be hoped that this one will prosper, as it surely should do in suitably dedicated hands. It is to be hoped and prayed that such a new journal will effectively inculcate, in a wide readership and their followers in everincreasing numbers, due appreciation of the need for, and developments in, environmental education for due protection of the Biosphere. At the same time it should inform educators and interested laymen on important environmental matters that are in need of dissemination which could range from local to holobiospheral.

\section{Periodical International Conferences and Publications Henceforth?}

For these and other reasons it is also to be hoped that the successors of the Berne conference on environmental education can be fully international in name as well as context, that they can be held in different continents or anyway countries at two- or three-yearly intervals henceforth, that their main papers and conclusions will be widely published (as has already been proposed in this instance), and that the next conference (for which an invitation has already been accepted to hold it in 1982 in a suitable country outside Europe), will focus effectively on the Biosphere. Indeed, if our proposal of an International Year of The Biosphere, or some practicable alternative (such as that suggested below), is activated as many are convinced it should be preferably in 1982 (cf. Vallentyne, 1980), this conference in the same year could well--with probable advantage all around - be an integral and major part of such observance and/or activity.

N.P.

\section{REFERENCES}

EHRLICH, Paul R., EHRLICH, Anne H. \& HOLDREN, John P. (1977). Ecoscience: Population, Resources, Management. W. H. Freeman, San Francisco, California: xvii + 1051, illustr.

FOUNDATION FOR ENVIRONMENTAL CONSERVATION (1977). The Reykjavik Imperative on the Environment and Future of Mankind. Environmental Conservation, 4(3), pp. 161-3. Reprinted 'With approved editorial adjustments' on pp. 629-34 of Growth Without Ecodisasters? (see bottom reference of Willard et al.).

HUGHES-EVANS, David (in press). The Berne Conference on Environmental Education. Environmental Conservation, 7(3), Autumn 1980 [in press for]

POLUNIN, Nicholas (1972). The Biosphere today. Pp. 33-52 and following Discussion and Addenda to page 64 in The Environmental Future: Proceedings of the first International Conference on Environmental Future, held in Finland from 27 June to 3 July 1977. Macmillan, London \& Basingstoke, and Barnes \& Noble, New York, N.Y.: xiv +660 pp., illustr.

POLUNIN, Nicholas [as 'N.P.'] (1980). Editorial: Actions for a new decade. Environmental Conservation, 7(1), pp. 1-2.

VALLENTYNE, John R. (1980). Early reactions to the concept of 'The International Year of The Biosphere'. Environmental Conservation, 7(2), pp. $97-9$.

VALLENTYNE, John R., STRICKLER, J. R. \& POLUNIN, Nicholas (1980). Proposal: International Year of The Biosphere. Environmental Conservation, 7(1), p. 2.

WILLARD, Beatrice E., ASIBEY, Emmanuel O. A., HOLDGATE, Martin W., FUKUSHIMA, Yoichi \& DODSON GRAY, Elizabeth \& David (1980). 'Ethics of Biospheral survival: A dialogue'. Pp. 505-535 and following discussion to p. 551 in Growth Without Ecodisasters? Proceedings of the Second International Conference on Environmental Future (2nd ICEF), held in Reykjavik, Iceland, 5-11 June 1977 (Ed. Nicholas POLUNIN). Macmillan, London \& Basingstoke, England, and Halsted Press Division of John Wiley \& Sons, New York, N.Y.: xxvi +675 pp., illustr.

*We also proposed our own excellent publishers of this Journal as suitable for the ncw one, and are delighted to announce, with permission of the sponsors (our collaborators, WERC, see pp. 91-2), that this has now been arranged to start through Elsevier Sequoia in 1981.- N.P.

\section{Battle for the Biosphere}

This note deals with some 'qualifications' to the widely enthusiastic support (cf. Cloud, 1980 [This issue, p. 92] ; Vallentyne, 1980 [this issue, pp. 97-9]) for our proposal (Vallentyne et al., 1980) to increase scientific, public, and ultimately political, focus on the Biosphere through designation of 1982 as 'The International Year of The Biosphere'. The main qualifications are: (1) concern over the relative novelty and technical nature of, and consequent lack of popular familiarity with, the term 'Biosphere'; (2) doubts as to the effectiveness of 'Years' in achieving their real objectives; and (3) realistic questions concerning the adequacy of planning-time - at least without pre-arranged financing-in relation to 1982.

In answer to the first qualification, we see no way in which public awareness can be increased adequately with- out reference to, and universal publicization of, the Biosphere as our planetary life-support system: the problem cannot be alleviated by running away from it but must be faced squarely and with resolve. Thus 'ecology' was used almost solely as a technical term until little more than a decade ago, and is of course a revered science of which the origins reach far back into antiquity and the name is more than a century old. Today it is in common and popular use as a word practically throughout the world and, for the general public, spells political and often militant (though generally well-meaning) action*. Much the same seems likely to happen to 'Biosphere' in the

*See, for instance, the Editorial 'Ecology and "Ecologists"' in our Spring issue of 1978 (Environmental Conservation, 5(1), p. 2, 1978). - Ed. 